Article

\title{
Unequal Inclusion: The Production of Social Differences in Education Systems
}

\author{
Marcus Emmerich ${ }^{1, *}$ and Ulrike Hormel ${ }^{2}$ \\ ${ }^{1}$ Institute of Education, Faculty of Economics and Social Sciences, University of Tübingen, Germany; \\ E-Mail: marcus.emmerich@uni-tuebingen.de \\ 2 Institute of Social Sciences, Faculty of Educational and Social Sciences, University of Education Ludwigsburg, Germany; \\ E-Mail: hormel@ph-ludwigsburg.de \\ * Corresponding author
}

Submitted: 31 March 2021 | Accepted: 20 May 2021 | Published: 16 September 2021

\begin{abstract}
The article raises the question of whether and how education systems produce social differences internally rather than reproducing pre-existing "external” inequalities. Linking Niklas Luhmann's theory of inclusion/exclusion with Charles Tilly's theory of categorical inequalities, and based on empirical data from various qualitative studies, the article identifies an "observation regime" epistemically constituting the social classification of students and legitimising organisational closure mechanisms in the school system. As an alternative to the "reproduction paradigm," a research approach guided by differentiation theory is proposed that takes into account that educational inequality operationally arises on the "inside" of the educational system and is caused by unequal inclusion processes.
\end{abstract}

\section{Keywords}

educational inequality; exclusion; inclusion; observation regime; social closure

Issue

This article is part of the issue "Education, Politics, Inequalities: Current Dynamics and Perspectives" edited by Kenneth Horvath (University of Lucerne, Switzerland) and Regula Julia Leemann (University of Teacher Education FHNW, Switzerland / University of Basel, Switzerland).

(C) 2021 by the authors; licensee Cogitatio (Lisbon, Portugal). This article is licensed under a Creative Commons Attribution 4.0 International License (CC BY).

\section{Introduction}

In recent decades, the guiding question of sociological research on educational inequality has been: Why do social inequalities persist in Western welfare-state democracies despite educational expansion? Since the late 1960s, the empirical insight that the formally enabled full inclusion into the education system did not provide sufficient opportunities for intergenerational mobility called for a theoretical explanation addressing inequality mechanisms. The "reproduction" concepts of both rational choice theorists (e.g., Boudon, 1974) and cultural Marxists (e.g., Bourdieu \& Passeron, 1977) supported the explanans of socioculturally determined (self-)selection of socially disadvantaged students and thus seemed to provide a plausible answer to the above question. The following considerations instead suggest that this initial question had finally focussed on the wrong side of the problem and still does: Due to neglecting the active role of educational organisations as inequality operators, researchers following the "reproduction paradigm" systematically overlook the possibility that educational inequalities result from unequal modes of inclusion into the system of organised education.

The article proposes an alternative approach that assumes that the inherent logic of organisational operations in the education system explains the production of inequalities. In Section 2, following classical approaches in sociology of education that take school organisation and school governance into account (e.g., Bommes \& Radtke, 1993; Cicourel \& Kitsuse, 1963; 
Gomolla \& Radtke, 2002; Mehan, 1992), the theoretical part of the article tries to complement this tradition with social closure theory that combines Charles Tilly's relational inequality theory (RIT) with Niklas Luhmann's operational theory of social systems and his concept of inclusion/exclusion (Section 3). Identifying an observation regime epistemically constituting and legitimising the social classification of students (Section 4), the empirical part of this article subsequently presents findings and data from various qualitative research projects that give insights into organisational closure mechanisms and the epistemic function of the regime (Section 5). We finally argue that the observation regime not only serves for the durability of educational inequalities, since it guides educational closure inside the school system; the regime also constitutes the "reproduction paradigm" in educational inequality research (Section 6).

\section{Beyond Methodological Groupism: How (Not) to Explain Educational Inequalities}

Research on educational inequality is persistently dominated by sociological approaches that mainly refer to "classical" allocation theories (Boudon, 1974; Bourdieu \& Passeron, 1977). Both Bourdieu's class theory and Boudon's stratification theory are based on a "reproduction paradigm" that explains educational inequality by social inequality and vice versa. The theoretically assumed "habitus" (Bourdieu) and learning abilities, according to "social heritage" (Boudon), construct a socio-ontological explanans for assumed "given" unequal "cognitive" and behavioural dispositions of students and their families (Brubaker, 1985; Emmerich \& Hormel, 2013b; Swartz, 1981).

Guided by Boudon's rational choice approach, German educational inequality mainstream research (e.g., Becker, 2011; Blossfeld et al., 2019) in particular follows the notion of an interplay between "primary" and "secondary effects of social stratification" (Boudon, 1974, p. 83) as the main cause for educational inequality. This is also true for current studies on the educational inclusion of students who immigrated during the so-called "refugee crisis" (e.g., Will \& Homuth, 2020). Special attention is paid to "secondary effects," which are conceptualised as class-specific educational aspirations and cumulative school choice decisions based on cost-benefit calculations. However, the methodological individualism of the rational choice paradigm proves to be a problem, not because "rational" school choice decisions are thought to be relevant, but because the methodological design of the primary effect is based on the metaphor of "social heritage": If "primary effects" are conceptualised as "inequalities in cognitive abilities generated in a child's formative years by differences in family background" (Blossfeld et al., 2019, p. 26), a strong theoretical assumption bears the burden of explanation, but this assumption itself cannot be empirically verified. Constructed as an independent variable predicting indi- vidual learning abilities at the time of school choice, this operationalisation neglects the brute fact that differentiating instructional efforts and learning interactions contaminate "cognitive abilities" with the student's first school contact. In addition to confounding sociocultural competencies with cognitive skills, the "primary effect" includes a school interaction effect that cannot be statistically controlled for.

Compared to Boudon, Bourdieus's differentiation theory at least proclaims a "relative autonomy" of the educational field (Bourdieu \& Boltanski, 1981), but due to the lack of an operational theory of organisation, the reproduction of class structure through habitus formation remains the only causal explanation for educational inequality (Kieserling, 2008). This is also the case for Bourdieu-oriented research that focuses on problems of the "cultural fit" between students and educational institutions (e.g., Kramer, 2017). Finally, Bourdieu's culturalisation of class theory and Boudon's culturalisation of stratification theory apparently lead to culturalist causalities (e.g., Brubaker, 1985; Jenkins, 1982), methodologically supporting what Brubaker (2004, p. 8) called "groupism," which is "the tendency to take discrete, bounded groups as... fundamental units of social analysis" (Brubaker, 2004, p. 8) in the field of cultural sociologies.

International comparative studies, however, cast doubt on the explanatory power of the reproduction paradigm. Their findings lead to ironically phrased questions like: "Are the children of Turkish immigrants in other countries smarter than in Germany?" (Wilmes et al., 2011, p. 101, translation by the authors). The results of the underlying comparative survey TIES (The Integration of the Second Generation) show that the intergenerational mobility of young people whose parents immigrated from Turkey varies considerably across the eleven European countries studied: While a vanishingly small proportion of this "group" gains access to higher education in the two German cities in the sample, in Stockholm and Paris "the second generation experiences a generalised strong upward social mobility in relation to their parents' generation" (Crul et al., 2012, p. 127). Beyond that, regional characteristics of class and migrationrelated educational disparities in the German school system have been stably demonstrated for decades (El-Mafaalani \& Kemper, 2017; Emmerich et al., 2020; Weishaupt \& Kemper, 2009). Since this variance cannot be plausibly explained by the assumed educationally relevant origin characteristics of disadvantaged students, as the reproduction paradigm would suggest, this leads to organisational factors that generate patterns of educational inequality.

A long tradition of empirical works based on the theory of social classifications make typifying, labelling, and grouping students the starting point of their analysis (e.g., Cicourel \& Kitsuse, 1963; Mehan, 1992; Mehan et al., 1986). Criticising the view of schools as "automatic reproduction machines, exacerbating or perpetuating 
social inequalities in mechanical ways" (Mehan, 1998, p. 255), these qualitative studies seek to shed light on the "black box" of the internal structures and dynamics of the educational process. Tyack and Tobin (1994), for example, describe how the introduction of grade levels in the US in the early 20th century let a group of students with "developmental delays" emerge. In this case, an organisational change triggers social differentiation inside the school system. Finally, all the above approaches in fact seek to explain phenomena of social differentiation through school differentiation and thus focus implicitly and explicitly on organised education.

Within the German context, particularly, the approach of "institutional discrimination" (Bommes \& Radtke, 1993; Gomolla \& Radtke, 2002) has further developed organisation-oriented inequality research. In conjunction with constructivist/social phenomenological organisational research and Luhmann's operational systems theory, Gomolla and Radtke's (2002) study on the "making of ethnic difference" provided a theoretically grounded analytical framework for empirically observing disadvantaging organisational mechanisms in local school systems. The study shows how discrimination emerges unintentionally as a result of routinised resource distribution and selection strategies following an opportunity structure provided by the organisational differentiation of school types.

Recent contributions referring to Charles Tilly's theory of categorical inequalities analyse social closure mechanisms in school systems as a genuine organisational variable (Domina et al., 2017; Emmerich \& Hormel, 2013a). Following on from this conceptualisation of organisations as simultaneously decision-making and sensemaking "machines," we attempt to present a theoretical and empirical approach to inequality research combining Tilly's (1999) analysis of organisation-based social closure mechanisms with Luhmann's concept of inclusion/exclusion to relate the production of inequalities with processes of social differentiation "beyond groupism" (Brubaker, 2004, p. 11).

\section{Organised Inequalities and Social Differentiation}

Further developing Tilly's approach, RIT particularly focuses on how social categories like gender, ethnicity, race, religion, nationality, education etc. become transformed into structures of "durable inequality" through organised social closure. RIT conceptualises organisations as societal "inequality regimes in their own right" (Tomaskovic-Devey \& Avent-Holt, 2019, p. 105) internally practising exploitation, social closure, and claims-making by which they affect the inequality structures of their local environment. Tilly's notion of "exterior" social categories being matched with "interior categories" (Tilly, 1999, pp. 74-84) that represent the hierarchy of organisational positions and legitimise exploitation refers to the new institutionalism thesis that organisations copy institutionalised values and norms from the social envi- ronment (Powell \& DiMaggio, 1991). Thus, RIT on the one hand overcomes the methodological groupism of inequality research since the concept assumes "generic inequality-producing mechanisms associated with categorical distinctions" that produce a local variance of inequality forms (Tomaskovic-Devey \& Avent-Holt, 2019, p. 106), but on the other hand, we see two conceptional issues.

First, if organisations were constituted by interacting individuals or "real people" (Tomaskovic-Devey \& Avent-Holt, 2019, p. 70), we would also methodologically need to assume that individuals were "doing" inequality inside an organisation through exploitation and social closure. In contrast, an operational theory of organising suggests that organisations "work" because they do what they do independently from concrete individuals or concrete interactions. Organisations are more complex sense and decision-makers (Weick et al., 2005) than the image of an aggregate of interacting people suggests.

Second, RIT conceptualises social closure as the core element of the organisational "inequality regimes" (Tomaskovic-Devey \& Avent-Holt, 2019, p. 70) and assumes that organisations "position a categorical boundary," thus regulating unequal access to resources and power (Tomaskovic-Devey \& Avent-Holt, 2019, p. 136). According to RIT, organisational closing takes place as a "status distinction" (Tomaskovic-Devey \& Avent-Holt, 2019, p. 136) between pre-existing social groups in a "situation in which one group excludes, intentionally or not, another categorically distinct group from assessing some organisational resource" (TomaskovicDevey \& Avent-Holt, 2019, p. 135). Although this interpretation of Max Weber's closure theory is widely established, it reproduces a misconception probably caused by the English translation: Weber did not use the term "group"; instead, he argued that by closure a "part" of competitors would become excluded "from competition" (Emmerich, 2020). Thus, social closure is defined as a specific process that generates a "part" of individuals without access to competition (not to "resources").

Weber had a complex operation in mind that symbolically categorises and materially divides individuals through enabling access/no access to societal areas such as markets, administration, military, and education, etc. The social closure concept indeed leads to a "relational" theory of inequality since it describes a social differentiation in which one part of the people has the chance to succeed or fail in competition because another part has no chance to either succeed or fail. Paradoxically, the English translation adds a methodological "groupism" to social closure theory that obscures the "group-making" done by closing operations.

RIT apparently lacks an operational theory of organisation, that is, a theory of what constitutes organisations, what they are "doing" and how they gain internal and external order through what they are doing. Instead, Luhmann (1995a) conceptualises social systems as dynamic, operationally closed ("autopoietic") but 
acausal operating communication systems. The system type "organisation" only consists of an operationally closed "stream" of decision-communication drawing a sense-based boundary between its inside and its outside, while membership closes an organisation against any social environment (Luhmann, 2018). Following constructivist and phenomenological organisation theory (Weick, 2001), the autopoietic organisation primarily works as an interpretation machine. Theorising organisations as operators for social inequality not only requires a notion of how organisations "do that." It also calls for an answer to the question of how organisations are linked with society, particularly with societal differentiation. Since "organisation" historically emerges as a modern societal system type, a functional analysis methodologically needs to reconstruct its "outdifferentiation" (Luhmann, 2018, p. 5) guided by the systematic question of what societal problem the observed solution (organisation) deals with. Since generating inequality is not the societal function resp. the basic "sense" of organising, we, therefore, need to focus on the question of what organising has to do with social differentiation. In clear contrast to former functionalist stratification theory (Davis \& Moore, 1945), the production of inequalities works as a solution for organisations, but not for society. Thus, the reference problems that drive organisations and pushes their internal dynamics must be found somewhere else.

According to Luhmann, organisation-based inclusion/exclusion operations relate individuals and society by addressing persons as relevant or non-relevant for systems communication (Luhmann, 1995b). Therefore, inclusion/exclusion can be conceptualised as a "polycontextural" organisational closure mechanism generating and relating social differentiation and inequality (Emmerich, 2020). Counter-intuitively, inequalities emerge on the "inclusion side" of the closing operation: Since no individual is categorically excluded from the (labour) market, economic inequalities result from unequal market transactions and since no individual is categorically excluded from access to public schooling, educational inequalities result from grouping and unequal allocating of students inside the school system. While inequality results from "inclusion," "exclusion" produces categorical social differences: The category "man" excludes the category "woman," "white" excludes "black," "disabled" excludes "non-disabled" and so on. By categorising, organisations turn individuals into exclusive group members and decide whether the categorical groups each meet the communication requirements of the observing organisation. Luhmann's theory of inclusion/exclusion thus provides a complex analytical approach allowing, firstly, to generalise the logic of "ethnicization" based on "boundary-making" (Wimmer, 2013) or "group-making" (Brubaker, 2004, p. 13) as a form of social differentiation and, secondly, to systematically observe how social group-making is operationally related to the societal production of inequality.

\section{The Observation Regime}

Insofar as we accept the notion that organisations do the "group-making" through including/excluding closure, we should further ask how they know how to do so. We propose to use the notion of "regime" to theorise the organisational linking between classificatory observing and organisation based social differentiation concerning its structural effects. Recent regime concepts assume that political power and domination became a globalised and network-based form (Keohane \& Nye, 1989). Traditional state-centred political theories fail in describing the complexity of actors, knowledge, and dynamics inside, outside and beyond the modern national welfare state. Therefore, regime theory uses insights of sociology of knowledge and constructivist/phenomenological sociology to make the sociocognitive dimension of "regime" that guides actors observable. Regimes can be seen as complex, multilevel producers of societal reality generating societal phenomena such as migration (Horvath, 2014), inequality (Tomaskovic-Devey \& Avent-Holt, 2019), justification (Boltanski \& Thévenot, 1999), classification (Keller, 2008) or education (Amos \& Radtke, 2007) through the establishment of categorical boundaries. However, dominated by action and actors' theories, the regime approach lacks a differentiation-theory capable of describing the endemic societal dynamics of societal order formation. Thus, mapping ideologies, interests and strategies of global networks and actors do not explain what actors are, what they do and how they-societally-emerge. From an operational systems theory point of view, we would suggest that "regimes" emerge as a societal form that requires the "outdifferentiation" of organisations. Without the societal capability of decision-making, no regime could generate any material social effect.

We propose to add the term observation regime to the existing list of regime types to highlight the socio-cognitive or sensemaking character of any regime working in any decision-making in any organisation. Observation acts "do things with categories" (Brubaker, 2004 , p. 13) inside and outside the organisation. Following Luhmann (1995a), societal systems are constituted by the ability to observe their social environment based on internally produced distinctions indicating "world" as a reality for themselves. Systems theory conceptualises observation as a performative operation. Particularly organisations materialise what they observe: By making decisions, they turn fiction into function. Following Althusser's (1977) theory of ideology, school systems thus function as ideological state apparatus constituting an "image" of society for the society: Seen as ideology, "exterior" categories would apparently "represent the imaginary relation" (Althusser, 1977, p. 133, translation by the authors) between school and society inside and for the observing school system. According to Luhmann's observation theory, exterior group categories thus "imagine" society from inside the school organ- 
isation as "exteriorised" interior categories. Referring to the Durkheimian and Foucauldian tradition, Douglas (1986) argues that institutions "work" as socio-cognitive operators implanting their classification systems within a society that becomes controllable this way. But only organisations can transform classification systems, as we pointed out, into faits sociaux; due to their ability to make decisions, organisations not only operate as societal "classificators" (Berger, 1988) but draw categorical boundaries between persons and produce social differentiation. Hence, observation regimes require organisations not only as "decision machines" but also (and foremost) as "observation machines." While Luhmann defines "distinction/indication" as the general modus observandi of societal systems, we would propose additionally to conceptualize "classification/ascription" as the specific modus in which organisational systems observe individuals (Emmerich \& Hormel, 2013a, pp. 82-89). Organisations materialise an observation regime by producing, copying, and pasting classifications to "match" them with internal demands on the one hand, but the regimes provide distinctions that enable organisations to construct and solve problems by classifying and ascribing "legitim" categories to persons on the other hand. Regimes and organisations are reciprocal parasites.

Making selection decisions is not the function of classroom interaction; nevertheless, instruction produces the only "legitimisable" meritocratic decision premises. In contrast, images of students' socio-cultural characteristics present a social environment that does not legitimise pedagogical differentiation. Hence, as premises, exteriorised categories support allocation decisions, but they do not support any single students learning progress. However, matching legitimate interior with illegitimate "exterior" categories invisibilises the socially constructed decision premises regulating access to highquality learning environments. Keeping refugee students away from academic school tracks would provoke political and moral critique, even within the organisationally tracked German school systems. However, keeping low-track students away from the academic track schools is part of the system's own foundational normativity and thus a legitimised cause for educational closure.

With explorative purpose, the following chapter will present empirical findings and data collected in several qualitative research studies that make an organisational closure mechanism as well as an observation regime visible.

\section{Empirical Explorations: Bypass Schooling and Social Mapping}

The school systems in German-speaking countries are well known for their differentiated tracking structure featuring an early and highly selective transition from elementary to lower secondary schools. Early tracking organisationally closes the access to high-quality learning opportunities due to different secondary school cur- ricula. German, as well as Swiss schooling, typically leads to either vocational or academic training. Only the Gymnasium provides direct access to university while the lowest secondary tracks (Hauptschule in Germany) offer precarious transition to either vocational training or the labour market. The German, as well as the Swiss "grammar of schooling" (Tyack \& Tobin, 1994), is characterised by ability-grouping processes on the organisational level (the so-called "external differentiation") particularly forcing primary schools to differentiate students from the first class on to generate decision premises for the early transition process.

Framed by this "grammar," the findings and data presented in the following chapter stem from various comparative case studies conducted in Germany and Switzerland within the last two decades on different organisational levels (local school governance, single schools, and professional interaction) of the school systems. Although the single studies were based on different research questions, designs, and methodological strategies (documentary method, grounded theory methodology), they all were guided by a "functional analysis" (Nassehi \& Saake, 2002) of observation operations and closure mechanisms inside the school organisation. Focussing on the desideratum we identified above, we selectively re-interpret the existing data with explorative purpose: The following functional analysis focuses on how schools construct and relate (loosely/tightly couple) problems and solutions in decision-making, and particularly, how schools design decision premises capable of enabling decision-making.

\subsection{Bypass Schooling as an Educational Closure Mechanism}

"Bypass schooling" (as we name it) is an organisational closing strategy we observed while reconstructing decision-making processes on the level of local school governance in Germany. The first project examines how newly immigrated students have been included and allocated within school structures of local school systems in two German states since 2014 (Emmerich et al., 2017; Emmerich et al., 2021). At the time the data collection started, the local school systems were set under decision-making pressure due to the fast-increasing number of students. Meanwhile, statistical evidence is given on the national level that the German school systematically "bypasses" refugee/newly migrated students to the low regular school tracks (Emmerich et al., 2020; Henschel et al., 2019). Reanalysing qualitative data from a mixed-methods study conducted in the Kanton of Zurich (Switzerland) 2014-2017 (Emmerich, 2016; Maag Merki et al., 2020), we find another version of bypass schooling performed inside schools. Focussing on learning support strategies of primary schools in socially disadvantaged inner-city quarters, the Swiss study analysed the relation between school-internal constructions of socio-spatial environments and differentiation practices. 
How does bypass schooling work and what kind of problems does it solve?

\subsubsection{How to Protect Academic School Tracks from Newly Immigrated Students}

Bypass schooling even seems to be part of the German school governance history. The German school has always responded to new migrants and refugees with compensatory special education measures in the form of a (two-year) preparatory class designed to enable the transition to regular school classes through targeted language support. Neither within the era of the so-called "guest worker" migration based on a "rotation"-strategy in the late 1960s nor during the refugee migration caused by the Yugoslav wars in the mid-1990s, was the full and durable educational integration of these students the politically aim of German school authorities. Preparatory classes were exclusively located in the Hauptschule as the lowest track (Radtke, 1996), keeping the "dysfunctional" immigrant students away from higher tracks was the long-term closure effect-intended or not. Bypass schooling occurred, as local school systems used preparatory classes for permanent schooling parallel to the regular school system until the early 1980s (Gomolla \& Radtke, 2002). From this time until now, newcomer students must be transferred from preparatory to regular classes after two years by school law. Furthermore, preparatory classes were never meant to provide an effective integration structure, even lacking a curriculum. Reactivated to deal with the so-called "refugee crisis" in 2015-2016, the "preparatory system" (separated as well as integrated) apparently performs its legitimised and routinised closure mechanism while internally producing a group of students with "learning risks," who by definition, are not predestined to compete in academic tracks.

With this historical analysis in mind, our intermunicipal comparative study, conducted in North RhineWestphalia and Baden-Württemberg, was designed to shed light on the black box of the local "newcomer" allocation systems. To understand how this system works, we reconstructed the sensemaking and decision-making on the level of local school governance. The following explorative re-analyses are based on documents such as laws, decrees, procedural regulations and expert interviews with representatives of the municipal integration management involved in organising the allocation of refugee/immigrant students to secondary schools. Interviews were conducted in seven cities in North Rhine-Westphalia in 2015-2016 ( $N=11$ ) and eleven urban and rural districts in Baden-Württemberg in 2018-2019 ( $\mathrm{N}=21)$.

Two examples from North Rhine-Westphalia show different bypass schooling solutions, but both work on the same organisational problem: Since the Hauptschule appeared to be a dead-end track with a nation-wide reputation of a "residual school" or "immigrant school" hardly offering any successful educational pathways, many local school boards in Germany decided and still decide to abolish this school type-and so did these two. In 2015, only a few places in Hauptschulen were available for refugee allocation. City $A$, therefore, decided to establish a separate preparatory school ("integration centre") exclusively educating the "newcomer" for two years. This school was managed by the local Gymnasia and the official school statistics listed the "newcomers" as Gymnasium students-although the preparatory school only bypassed the newcomers for two years channelling them to low or SEN-school tracks. In 2020, this irregular "preparatory school" was officially transformed into a regular Hauptschule, which re-established this formerly abolished school type.

City $B$, in contrast, decided not to reactivate the Hauptschule due to political reasons, but installed a complex system of bypass schooling solutions instead: First, setting up new Hauptschule-tracks at the secondary modern school types (Realschulen) was a decision made to enable the local school system to bypass newcomers as Hauptschüler within and parallel the higher school tracks. Second, the local allocation system sends the newcomers to single comprehensive schools (providing a Hauptschule certificate) which have the reputation of "immigrant schools." Confirmed by the local school board's decision in 2018 that newly immigrated children should generally be allocated to comprehensive schools to "secure their school career," the local system was enabled to de facto treat newcomers as Hauptschüler although de jure this school type does not exist any longer. However, closing academic tracks against Hauptschüler is still a legitim differentiation practice while closing academic tracks against refugees is not.

Protecting secondary higher schools from immigrant newcomers in these local systems is done by constructing decoupled passageways beyond or even loosely coupled to the "grammar of schooling." Furthermore, the closing mechanism works due to interior categories such as "side-entrants," "school type changers" or simply Hauptschüler ascribed to the refugee or immigrant newcomers, each addressing an operational problem tightly coupled to these students. Bypass schooling epistemically makes sense because it is taken for granted that newcomers are natural Hauptschüler. This is what we can find in every local school system we observed.

\subsubsection{How to Internally Gentrify Schools}

Another version of bypass schooling can be observed within the context of the second project which investigated learning support strategies of segregated primary school in socially disadvantaged quarters in Zurich that were facing an on-going gentrification dynamic pushing mostly immigrant families out of the neighbourhood (for research design and results in detail see Maag Merki et al., 2020). Some of the primary schools had to react to the change in their social environment since the mismatch between the established support measures 
that were addressing socially deprived migrant students and the demands and high educational aspirations of the "new" academic Swiss and German parents now inhabiting the school district. Traditionally, only very few of their students successfully realise transition to an academic school career, but gentrification brings middle-class parents to the quarter expecting the schools to serve for the future academic careers of their children.

Switzerland has a six-year primary school leading to either academic or vocational secondary tracks. Compared to the four-year primary school in the majority of German states, the responsibility for successfully preparing students for academic tracks appears to be more pronounced. To meet the needs of the new group of students, some schools redefine the former "supporting" classes, accessible only to the high-achieving immigrant students, as a measure to ensure the school success of social "newcomers" of Swiss or German origin. Apparently, a temporarily practised social decomposition of classes functions as a closure mechanism that "protects" high-achieving Swiss and German students from the majority of socially disadvantaged migrant students.

While in the first case (Section 5.1.1) the minority immigrant "newcomers" has been bypassed to a scholastic dead end, in this case, the minority of socially privileged Swiss and German "newcomers" has been bypassed on a fast track to higher education. In both cases, bypass schooling not only protects one part of the students from competing with another part, it makes the two parts emerge as different social groups.

\subsection{An Observation Regime at Work: Mapping and Matching}

The following findings provide insight into what an observation regime consists of and how it works as part of organisational decision-making in schools. Its function is to gain legitimisable decision premises for an observing system by providing a range of group categories that can be ascribed to persons. We use data (interview sequences translated by the authors) from various research projects situated at different system levels (school administration, single schools, profession) to reconstruct an observation regime operating on and across different levels.

As already presented above, the constant classification of newly immigrated students as Hauptschüler epistemically legitimised bypass schooling at the level of school governance. As shown, the systems memory function still works even if there is no longer a Hauptschule available to allocate students. The political decision to abolish the Hauptschule in City 2 by example becomes a case of critical self-observation facing the "refugee crisis," as a municipal decision-maker finds:

We have a problem here that we have no more Hauptschulen.
In line with this problematisation, a decision-maker from another city formulates:

For example, we have the Hauptschulen, which are all full at the moment. And in the future, we might have to move away from allocating them directly to a particular type of school, right?

Apparently, the school system historically "learned" to match the exteriorised category "immigrant" student to the interior category Hauptschüler-and has not unlearned this ever since. The system even seems to turn the matching into a normative prescription which determines to observe immigrant students that way even if this leads to a decision-making struggle. The boundary the matching constitutes between newcomers and regular students evokes an epistemic plausibility unable to become falsified inside the school system. The notion that newcomers shall not be classified as "dysfunctional students" due to a lack of language skills has never emerged within the data. Instead, we assume that boundary-making is crucial for gaining observation opportunities inside the system since it epistemically legitimises the group-making, that is, the educational closure.

Professional organisations such as schools depend on members educated in classifying persons for the demands of the organisation. In school systems, the work of classifying is done by professionalised teachers observing the classroom interaction at the front line of the education system. Another view on the observation regime can be found in teachers imagining a social world outside, inhabited by students carrying their "socio-ecological origins" inside the classroom. A primary school teacher in Zurich said:

So, and these children are in tension, right? And then the question is really... how much is it encroachment when you start to interfere with the parents, or...? Because they have their own style, their own-we talk about habitus in sociology-their own habitus. And then you say: This is wrong, and this is wrong. I mean, we don't say it like that; but still, they notice, of course, right?

Paradoxically, the translation of Bourdieu's theory of habitus into an educational social ontology provides an epistemically plausible decision premise-the sociocultural misfit of family and school, which explains why a future academic school career should not be "forced." Furthermore, matching sociological with pedagogical categories apparently makes cognitive differences become "observable," even if there has been no interaction with the concrete students. Asked about what "heterogeneity" primary teachers expect from new first-graders they do not know yet, a primary school teacher from Germany answers: 
Yes, well I don't want to talk about social classes now, but there are already [laughs] - I have to say it a bit more diplomatically [laughs] - parents who are maybe a bit simpler in their whole possibilities, in their way of thinking.

The confounding of presupposed socio-cultural competencies and "cognitive abilities" in this case reformulates the idea of a "primary effect" based on "social heritage." Intended or not, the reproduction of Boudon's version of the reproduction paradigm is remarkable. It is interesting to see that and how the two primary school teachers refer to a whole "theory of society" that brings the exterior sociological category "habitus" and "social classes" into the classroom. Making the theories of socio-cultural "misfit" and "primary effect" a pedagogical faits social provides "observable" predictors for further school success.

Another example from a Hauptschule in the SouthWest of Germany confirms the intuition that even scientific theories are part of the observation regime. According to a teacher from Germany:

So, quite clearly: PISA brings to light what we feel every day. We have in the Hauptschule exactly the students... well, what PISA says, the underclass children slip through the grate. And these underclass children, we have them here.... But we have certainly $80 \%$ migrant children here who are not proficient in the German language....I do not see that we can achieve the goal of qualifying them to such an extent that they can take up these somewhat higher-qualified professions.

Comparable to the "habitus" example, the unconventional reinterpretation of the scientific-sounding PISA findings provides a plausible explanation for why the school is incapable of successfully working with students. In terms of the classificatory logic of observation regime, this example also shows an important aspect that is finally generalisable to every finding we present: By using sociological categories, the teachers create a causal image of the relation between school and society in which the school is passive whereas society is the active part in the game. Constantly streaming into the school system in the form of students, society disturbs the school's internal educational process. In this case, the slipped-through "dysfunctional" students paradoxically appear to disable high-quality classroom instruction and hinder the school in succeeding educationally.

Schools also develop socio-spatial classifications mapping their local social world, which is primarily guided by organisational variables such as school district boundaries or housing programs. Gentrification processes not only change these variables outside but also inside the classroom. Thus, the relevant social world "outside" needs to be re-mapped:
I notice that in these six children that I now have from this settlement, so these are worlds. These are children who suddenly have a very good German, who simply-it's not about German now, but I somehow notice that this is a little bit of a higher class. (Primary School Teacher, Zurich)

Regionally it is in fact, yes, from the catchment area there are a few groups of houses somehow there; one says yes there could be problems. (Primary School Teacher, Germany)

In the first map, language is relevant as a social stratification category, not as a communication category; the operational issues caused by lacking language skills are social issues caused by socio-economic background. As mentioned before, exterior categories represent the "imaginary relation" between the school system and society for the observing school. The six new children are "functional" due to their class membership. They better "fit" the demands of schooling because of their sociocultural habitus; it is a Bourdieu-map. The second map is a causal map that provides a preventive socio-spatial observing that makes pedagogical problems not only expectable but likely. However, both maps emerge from inside the school system.

\section{Unequal Inclusion: Why Is It So Hard to Change?}

Our data shed light on a general operational mechanism of social differentiation as an effect of educational closure. The empirical findings made an operating school system visible, which by routine does what it is used to do. We reconstructed a usual and taken-for-granted logic of boundary- and group-making performed by senseand decision-making processes on the organisational level of the school system. Inventing group categories and coupling them with organisational purposes thus appears to be part of an institutionalised closing routine varying on the different internal system levels as well as in the spatial dimension of school organisation.

Recent international research on tracking phenomena particularly focusses on comprehensive school systems of the Anglo-American type (e.g., Domina et al., 2019), generating informal "hidden" tracking structures. However, our findings can show as well an implicit "hidden" tracking practice one would not expect to find within the "grammar" of a formalised explicit German (or Swiss) type tracking system. Although the complex organisational differentiation of the German and Swiss school systems appeared to provide an already visible and sufficient opportunity structure for streaming, tracking, and grouping, research on implicit tracking strategies apparently needs to be highlighted as a desideratum. Furthermore, the phenomenon of bypass schooling raises the question of whether discriminatory effects can be qualified as "unintended" and "indirect" (Gomolla \& Radtke, 2002), for the local school systems we observed 
flexibilise their formally constituted selection structure with a complex interplay between school governance, decision-making on the school level and classificatory observations on the classroom level to perpetuate their discriminatory capability. From an organisational perspective, research on education inequality mechanisms should consider school structures as a dependent variable that changes over time and space.

What we called the "observation regime" makes different classification systems compatible and provides orientation in decision-making due to constituting "cognitive" legitimacy: While the exterior observationcategories in use present a relation between school and society for the school system, these categories generate the image of a "passive" school that can only react on a dynamic and unpredictable society. By mapping and matching the socio-ontological "nature" of the students, the observation regime not only says that what is "real" outside is "real" inside. It causally explains and legitimises an internal closure mechanism that aims at preventing the school from getting operationally "dysfunctionalised" by the "dysfunctional" students streaming in from "outside." From the system's self-observation point of view, practising unequal inclusion appears to be a legitimate self-defence strategy. Furthermore, the observed matching of categories creating new boundaries and groups for the system cannot be explained as a reaction to socio-environmental dynamics such as a "refugee crisis" or increased gentrification processes. Social classifying is rather a general modus observandi enabling the school systems to design "social problems" in such a way that the system is capable of processing them on its operational level.

What we can also see from this level of abstraction is mainstream educational inequality research guided by the same observation regime. Boudon and Bourdieu conceptualise the school as a passive actor, be it an arena of cultural class war (Bourdieu) or an independent variable of school-choice opportunities (Boudon). It makes a difference whether the school is viewed as an institution systematically privileging the academic classes (Bourdieu) or as an opportunity structure that fosters socially selective rational educational choices (Boudon). However, in both cases, the theoretical bias toward explanatory factors external to the school obscures the active role school systems play in the societal production of education inequality. Based on the same group categories, the school system processes social differentiation through educational closure (bypass schooling) while the researcher following the reproductionparadigm explains the production of educational inequality through social differences (self-selection from higher education). In both cases, the active/passive scheme provides explanation and legitimation.

Tyack and Tobin (1994) stated that the grammar of schooling seems so hard to change due to organisational features and professional routines that turned out to be useful for the operating school system. What we find in addition is a "hidden grammar" (bypass schooling) driven by an observation regime which de facto protects the "regular" grammar. Thus, what we can learn from the observed schools is how organisational resilience works in cases of social change. Furthermore, we also need to ask if the "grammar" of educational inequality research might be part of the problem. Maybe it is so hard to change due to the research routines and epistemic beliefs it protects. Therefore, we would suggest educational inequality research based on complex social differentiation theory capable of uncovering the generic mechanisms of a locally, regionally, nationally constituted educational inequality. This research program firstly requires an advanced theory of organised education to partially change the grammar of sociological observation of inequalities.

\section{Acknowledgments}

We would like to thank the editors of the thematic issue as well as the anonymous reviewers for their very helpful and insightful comments and suggestions.

\section{Conflict of Interests}

The authors declare no conflict of interests.

\section{References}

Althusser, L. (1977). Ideologie und ideologische Staatsapparate. Aufsätze zur marxistischen Theorie [Ideology and ideological state apparatuses. Essays on marxist theory]. VSA.

Amos, K., \& Radtke, F. O. (2007). Die Formation neuer Bildungsregime: Zur Durchsetzung von neuen Regierungstechniken in der post-nationalen Konstellation [The formation of new educational regimes: On the penetration of governance techniques in the post national constellation]. In M. Brumlik \& H. Merkens (Eds.), Bildung, Macht, Gesellschaft [Education, power, society] (pp. 293-303). Barbara Budrich.

Becker, R. (2011). Entstehung und Reproduktion dauerhafter Bildungsungleichheiten [Emergence and reproduction of durable educational inequalities]. In R. Becker (Ed.), Lehrbuch der Bildungssoziologie [Textbook of the sociology of education] (pp. 85-129). Springer.

Berger, P. A. (1988). Die Herstellung sozialer Klassifikationen: Methodische Probleme der Ungleichheitsforschung [The making of social classifications: Methodological problems of inequality research]. Leviathan, 16(4), 501-520.

Blossfeld, G., Blossfeld, P., \& Blossfeld, H. P. (2019). A sociological perspective on education as a lifelong process. In Becker, R. (Ed.), Research handbook on the sociology of education (pp. 18-34). Edward Elgar. 
Boltanski, L., \& Thévenot, L. (1999). The sociology of critical capacity. European Journal of Social Theory, 2(3), 359-377.

Bommes, M., \& Radtke, F.-O. (1993). Institutionalisierte Diskriminierung von Migrantenkindern. Die Herstellung ethnischer Differenz in der Schule [Institutionalized discrimination against immigrant children. The making of ethnic differences in school system]. Zeitschrift für Pädagogik, 39(3), 483-497.

Boudon, R. (1974). Education, opportunity, and social inequality: Changing prospects in Western society. Wiley.

Bourdieu, P., \& Boltanski, L. (1981). Titel und Stelle. Zum Verhältnis von Bildung und Beschäftigung [Titles and jobs: On the relation between education and employment]. In P. Bourdieu, L. Boltanski, M. de Saint Martin, \& P. Maldidier (Eds.), Titel und Stelle. Über die Reproduktion sozialer Macht [Titles and jobs. On the reproduction of social power] (pp. 89-115). Europäische Verlagsanstalt.

Bourdieu, P., \& Passeron, J.-C. (1977). Reproduction in education, society and culture. SAGE.

Brubaker, R. (1985). Rethinking classical theory: The sociological vision of Pierre Bourdieu. Theory and Society, 14(6), 745-775.

Brubaker, R. (2004). Ethnicity without groups. Harvard University Press.

Cicourel, A. V., \& Kitsuse, J. I. (1963). The educational decision-makers. Bobbs Merril.

Crul, M., Schnell, P., Herzog-Punzenberger, B., Wilmes, M., Slootman, M., \& Gómez, A. (2012). School careers of second-generation youth in Europe. Which education systems provide the best chances for success. In M. Crul, J. Schneider, \& M. Lelie (Eds.), The European second generation compared (pp. 101-164). University Press.

Davis, K., \& Moore, W. E. (1945). Some principles of stratification. American Sociological Review, 10(2), 242-249.

Domina, T., McEachin, A., Hanselman, P., Agarwal, P., Hwang, N., \& Lewis, R. W. (2019). Beyond tracking and detracking: The dimensions of organizational differentiation in schools. Sociology of Education, 92(3), 293-322.

Domina, T., Penner, A., \& Penner, E. (2017). Categorical inequality: Schools as sorting machines. Annual Review of Sociology, 43(1), 311-330.

Douglas, M. (1986). How institutions think. Syracuse University Press.

El-Mafaalani, A., \& Kemper, T. (2017). Bildungsteilhabe geflüchteter Kinder und Jugendlicher im regionalen Vergleich. Quantitative Annäherungen an ein neues Forschungsfeld [Educational participation of refugee children and youth in regional comparison. Quantitative approaches to a new field of research]. Zeitschrift für Flüchtlingsforschung, 1(2), 173-217.

Emmerich, M. (2016). Organisierte Erziehung und kategoriale Ungleichheit [Organized education and cat- egorical inequality]. In R. Leemann., C. Imdorf, J. Powell, \& M. Sertl. (Eds.), Wie Bildung organisiert wird. Soziologische Analysen zu Schule, Berufsbildung, Hochschule und Weiterbildung [How education is organised. Sociological analyses of school, vocational training, higher education, and advanced training] (pp. 126-146). Beltz Juventa.

Emmerich, M. (2020). Inclusion/exclusion: Educational closure and social differentiation in world society. European Educational Research Journal. Advance online publication. https://doi.org/10.1177/14749 04120978118

Emmerich, M., \& Hormel, U. (2013a). HeterogenitätDiversity-Intersektionalität. Zur Logik sozialer Unterscheidungen in pädagogischen Semantiken der Differenz [Heterogeneity-diversity-intersectionality. The logic of social distinctions in educational semantics of difference]. Springer.

Emmerich, M., \& Hormel, U. (2013b). Ungleichheit als Systemeffekt? Schule zwischen sozialstruktureller Reproduktion und operativer Eigenrationalität [Inequality as a system effect? Schools between socio-structural reproduction and operational autorationality]. In F. Dietrich, N. Thieme, \& M. Heinrich (Eds.), Bildungsgerechtigkeit jenseits von Chancengleichheit [Educational equity beyond equality of opportunity] (pp. 137-158). Springer.

Emmerich, M., Hormel, U., \& Jording, J. (2017). Prekarisierte Teilhabe. Fluchtmigration und kommunale Schulsysteme [Precarious participation. Refugee migration and local school systems]. Die Deutsche Schule, 109(3), 209-222.

Emmerich, M., Hormel, U., \& Kemper, T. (2020). Bildungsteilhabe neu migrierter Schüler/-innen in NordrheinWestfalen: Regionale Disparitäten und überregionale Allokationsmuster [Participation in education of new migrant pupils in North Rhine-Westphalia: Regional disparities and supra-regional allocation patterns]. Zeitschrift für Soziologie der Erziehung und Sozialisation, 40(2), 133-151.

Emmerich, M., Sudermann, Y., \& Brinkmann, L. (2021). Flucht/Migration und Local School Governance. Eine vergleichende Fallstudie in BadenWürttembergischen Kommunen [Flight/migration and local school governance. A comparative case study in Baden-Württemberg communities]. In N. Beck, T. Bohl, \& S. Meissner (Eds.), Vielfältig herausgefordert. Forschungs- und Entwicklungsfelder der Lehrerbildung auf dem Prüfstand [Diversely challenged. Research and development fields of teacher education on the check] (pp. 117-133). University Press.

Gomolla, M., \& Radtke, F.-O. (2002). Institutionelle Diskriminierung. Die Herstellung ethnischer Differenz in der Schule [Institutional discrimination. The making of ethnic differences in school system]. Leske + Budrich.

Henschel, S., Heppt, B., Weirich, S., Edele, A., Schipolowski, S., \& Stanat, S. (2019). Zuwande- 
rungsbezogene Disparitäten [Migration-related disparities]. In P. Stanat, S. Schipolowski, N. Mahler, S. Weirich, \& S. Henschel (Eds.), IQB-Bildungstrend 2018. Mathematische und naturwissenschaftliche Kompetenzen am Ende der Sekundarstufe I im zweiten Ländervergleich [IQB education trend 2018. Mathematics and science competencies at the end of lower secondary school in the second country comparison] (pp. 295-331). Waxmann.

Horvath, K. (2014). Die Logik der Entrechtung: Sicherheits- und Nutzendiskurse im österreichischen Migrationsregime [The logic of deprivation of rights: Security and utility discourses in the Austrian migration regime]. Vandenhoeck und Rupprecht.

Jenkins, R. (1982). Pierre Bourdieu and the reproduction of determinism. Sociology, 16(2), 270-281.

Keller, R. (2008). Diskurse und Dispositive analysieren: Die wissenssoziologische Diskursanalyse als Beitrag zu einer wissensanalytischen Profilierung der Diskursforschung [Analysing discourses and dispositifs: Profiling discourse research in the tradition of sociology of knowledge]. Historical Social Research, 33(1), 73-107.

Keohane, R. O., \& Nye, J. S. (1977). Power and interdependence. World politics in transition. Scott, Foresman and Comp.

Kieserling, A. (2008). Felder und Klassen: Pierre Bourdieus Theorie der modernen Gesellschaft [Fields and classes: Pierre Bourdieu's theory of modern society]. Zeitschrift für Soziologie, 37(1), 3-24.

Kramer, R.-T. (2017). "Habitus" und "kulturelle Passung." Bourdieusche Perspektiven für die ungleichheitsbezogene Bildungsforschung ["Habitus" and "cultural fit." Bourdieu's perspectives for inequalityrelated educational research]. In M. Rieger-Ladich \& C. Grabau (Eds.), Pierre Bourdieu: Pädagogische Lektüren [Pierre Bourdieu: Pedagogical readings] (183-205). Springer.

Luhmann, N. (1995a). Social systems. Stanford University Press.

Luhmann, N. (1995b). Inklusion und Exklusion [Inclusion and exclusion]. In N. Luhmann (Ed.), Soziologische Aufklärung [Sociological enlightment] (pp. 237-264). Westdeutscher Verlag.

Luhmann, N. (2018). Organization and decision. Cambridge University Press.

Maag Merki, K., Buehlmann, F., Kamm, C., Truninger, A., \& Emmerich, M. (2020). Support of students in primary schools: A comparative case study in a selective education system. Journal of Curriculum Studies, 53(3), 279-297.

Mehan, H., Hertweck, A., \& Meihls, J. L. (1986). Handicapping the handicapped: Decision making in students' educational careers. Stanford University Press.

Mehan, H. (1992). Understanding inequality in schools: The contribution of interpretive studies. Sociology of Education, 65(1), 1-20.

Mehan, H. (1998). The study of social interaction in edu- cational settings: Accomplishments and unresolved issues. Human Development, 41, 245-269.

Nassehi, A., \& Saake, I. (2002). Kontingenz: Methodisch verhindert oder beobachtet? Ein Beitrag zur Methodologie der qualitativen Sozialforschung [Contingency: Methodically eliminated or observed? A contribution to the methodology of qualitative research]. Zeitschrift für Soziologie, 31(1), 66-86.

Powell, W. W., \& DiMaggio, P. J. (Eds.). (1991). The new institutionalism in organizational analysis. University of Chicago Press.

Radtke, F.-O. (1996). Seiteneinsteiger. Über eine fragwürdige Ikone der Schulpolitik [Side entrants. About a questionable icon of educational policy]. In G. Auernheimer \& P. Gstettner (Eds.), Jahrbuch für Pädagogik. Pädagogik in multikulturellen Gesellschaften [Annual of pedagogy. Pedagogy in multicultural societies] (pp. 49-63). Peter Lang.

Swartz, D. (1981). Classes, educational systems \& labor markets: A critical evaluation of the contributions by Raymond Boudon and Pierre Bourdieu to the sociology of education. European Journal of Sociology, 22(2), 325-353.

Tomaskovic-Devey, D., \& Avent-Holt, D. (2019). Relational inequalities: An organizational approach. Oxford University Press.

Tilly, C. (1999). Durable inequality. University of California Press.

Tyack, D., \& Tobin, W. (1994). The "grammar" of schooling: Why has it been so hard to change? American Educational Research Journal, 31(3), 453-479.

Weick, K. E. (2001). Making sense of the organization. Blackwell.

Weick, K. E., Sutcliff, K. M., \& Obstfield, D. (2005). Organising and the process of sensemaking. Organization Science, 16(4), 409-421.

Weishaupt, H., \& Kemper, T. (2009). Zur nationalitätenspezifischen und regionalen Bildungsbenachteiligung ausländischer Schüler unter besonderer Berücksichtigung des Förderschulbesuchs [On the nationalityspecific and regional educational disadvantage of foreign pupils with special reference to special needs school attendance]. In I. Sylvester, I. Sieh, M. Menz, H.-W. Fuchs, \& J. Behrendt (Eds.), Bildung, Recht, Chancen [Education, law, opportunities] (pp. 97-111). Waxmann.

Will, G., \& Homuth, C. (2020). Education of refugee adolescents at the end of secondary school: The role of educational policies, individual and family resources. Soziale Welt, 71(1/2), 160-200.

Wilmes, M., Schneider, J., \& Crul, M. (2011). Sind die Kinder türkischer Einwanderer in anderen Ländern klüger als in Deutschland? Bildungsverläufe in Deutschland und im europäischen Vergleich: Ergebnisse der TIES-Studie [Are the children of Turkish immigrants in other countries smarter than in Germany? Educational trajectories in Germany and in European comparison: Results of the TIES study]. 
In U. Neumann \& J. Schneider (Eds.), Schule mit Migrationshintergrund [School with migration background] (pp. 30-46). Waxmann.
Wimmer, M. (2013). Ethnic boundary making. Institutions. Power. Networks. Oxford University Press.

\section{About the Authors}

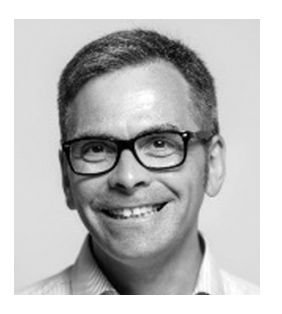

Marcus Emmerich, a Sociologist and Educational Scientist, is Professor in Educational Sciences with a focus on inclusion and diversity at the Institute of Education, University of Tuebingen, Germany. His theoretical and empirical research includes, among others, societal processes of inclusion/exclusion and the production of social inequality in education systems.

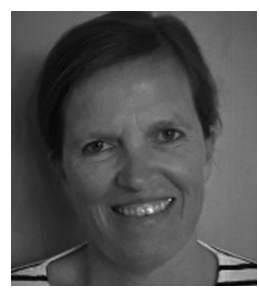

Ulrike Hormel is Professor of Sociology at the Institute of Social Sciences, Ludwigsburg University of Education, Germany. Her main research includes sociological analyses of educational inequality and migration, currently with a focus on the inclusion of newly immigrated/refugee students in local school systems. 